The Review of Finance and Banking

Volume 13, Issue 2, Year 2021

http://dx.doi.org/10.24818/rfb.21.13.02.05, Pages 147-160

S print ISSN 2067-2713 online ISSN 2067-3825

\title{
BANK REVOLVING CREDIT AS A CHANNEL OF MONETARY POLICY
}

\author{
MUJTABA ZIA AND JENNIFER LOGAN
}

\begin{abstract}
This paper investigates the implication of bank revolving credit in the form of credit card loans as a channel of monetary policy targeting the federal funds rate since 1980. Credit cards have become increasingly popular and a necessity for many transactions and purchases in the United States. The revolving credit nature of credit card loans makes them an instant tool for consumer loans that can facilitate consumption. Using instrumental variable and two-stage least squares (2SLS) methodology, we analyze the implication of credit card loans to modern monetary policy that targets interest rates.
\end{abstract}

\section{INTRODUCTION}

In recent decades, "[t]he federal funds rate has emerged as the key target of monetary policy in the United States." (Drechsler et al. 2018, 329). Bernanke and Blinder $(1992,917)$ observe "the federal funds rate, or perhaps the spread between the funds rate and some other interest rate is a good indicator of monetary policy." While interest rates remained the main target of monetary policy, the financial crisis of 2007-2008 compelled major central banks around the world, especially the Federal Reserve System (the Fed) in the United States, to go beyond the conventional monetary policies and directly intervene in financial markets. To address the credit crunch and prevent the collapse of certain short-term funding markets such as the commercial paper and mortgage back securities markets, the Fed became directly involved in the securities markets. The Fed created a series of unprecedented emergency lending facilities and auctioned off billions of dollars to target specific segments of the financial market such as the commercial paper market, mortgage-backed securities market, and the primary dealer credit market (Goodfriend 2011; Zia et al. 2018). Nonetheless, interest rates remained the main policy target of the Fed.

The Fed continues to set target rates for the federal funds rate (henceforth, the fed funds rate) to influence the cost of loanable funds, and therefore, the state of the economy. Announcements about the fed funds rate are the most closely watched events regarding the directional targets of monetary policy. The fed funds rate has fluctuated considerably since the 1970s. It increased from single high-digit percentages in the 1970 s to $16 \%-17 \%$ in the early 1980 s and fell again to low single-digit percentages after the financial crisis of 2007-2008. It reached its lowest level at $0.07 \%$ in the fourth quarter of 2011, excluding the $0.05 \%$ level in May of 2020 due to the Covid-19 pandemic.

Received by the editors September 22, 2021. Accepted by the editors December 23, 2021.

Keywords: Bank Revolving Credits; Credit Cards; Monetary Policy; Financial Crisis.

JEL Classification: E43, E51, E52, G01.

Mujtaba Zia, PhD *(Corresponding Author), Assistant Professor of Business-Finance, School of Business, University of North Texas Dallas, 7400 University Hills Blvd, FH 329, Dallas, Texas 75241, USA. E-mail: mujtaba.zia@untdallas.edu.

Jennifer Logan, PhD, Professor of Economics, Rankin College of Business, Southern Arkansas University, 100 E. University, MSC 9285, Magnolia, Arkansas 71753, USA. E-mail: jllogan@saumag.edu.

This paper is in final form and no version of it will be submitted for publication elsewhere. 
Expansionary monetary policy and quantitative easing decrease the cost of borrowing through decreased interest rates, encouraging investment and/or consumption, increasing aggregate demand, and thus boosting the real economy. The main mechanism through which monetary policy affects the state of the economy is through aggregate consumption, as it comprises more than $70 \%$ of the gross domestic product (GDP) in the United States ${ }^{1}$. In recent decades, researchers document inefficacies in the transmission of monetary policy. One of the complications that has been overlooked in the process of monetary policy is the rising popularity of consumer revolving credit in the last few decades. The rising popularity of revolving credit in the form of credit cards in the past few decades and their readily available credit feature facilitate considerable convenience in transactions and serve as instant loans for consumers. With the invention of the Internet, point of purchase transactions, automatic dispensing machines, and online shopping, credit card use has become common practice for U.S. households. These developments have made credit cards indispensable elements of US household financials and thus an important aspect of household consumption.

Since their introduction in 1951, the use of credit cards has increased by more than 700 times ${ }^{2}$. Over the past two decades, credit cards have exponentially become popular and an important aspect of American household financials. In the first quarter of 1968, the total amount of credit card debt outstanding was $\$ 1.4$ billion. By contrast, the total credit card debt reached $\$ 250.9$ billion by the end of 1990 and $\$ 1.041$ trillion by August 2018, all adjusted for inflation ${ }^{3}$. These figures indicate that credit cards play an important role in households' purchasing power, enabling them to finance daily consumption as well as certain durable goods. Therefore, credit card loans should be considered an integral part of consumption and monetary policy. The current research literature on monetary policy lacks sufficient coverage of credit card loans. We attempt to fill this gap in the literature with an empirical investigation of credit card loans and their implications for monetary policy.

The primary contribution of this paper is an empirical investigation of the responsiveness of aggregate consumption through the credit card channel in the context of monetary policy that targets the fed funds rate. Particularly, we study whether changes in the fed funds rate affect credit card rates and consumer spending financed by credit card loans. The secondary contribution of this paper is identifying one of the reasons for monetary policy inefficacies documented in the research literature. This extension to the existing monetary policy literature allows us to observe how household consumption responds to monetary policy that targets the fed funds rate. It is important for policymakers to understand the implications of monetary policy efforts and the impact those efforts might have on the average household consumption expenditures. It helps policymakers craft more effective monetary policy actions when they aim to bolster household consumption.

The remainder of this paper proceeds as follows. In section 2, we review the literature and outline prior research conducted in this area. In sections 3 and 4 , we present the data and methodology. In section 5 , we discuss the results, and in section 6 , we conclude with a summary and remarks.

\section{Literature Review}

2.1. The stance of monetary policy. The primary target of monetary policy in the United States is the interest rates, particularly, the federal funds rate. The transmission mechanism through which the Fed aims to influence the state of the economy is the lending channel or loanable funds market, whereby fluctuations in interest rates lead to changes in the cost of

\footnotetext{
${ }^{1}$ The average aggregate consumption as a percentage of GDP is $71.65 \%$ based on quarterly data between 1980q1-2018q4 from the Federal Reserve Bank of St. Louis.

${ }^{2}$ Authors' estimation by dividing the outstanding aggregate credit card debt in August 2018 by the number in the first quarter of 1968 . The actual result is approximately 743.57 .

${ }^{3}$ Source: Board of Governors of the Federal Reserve System: Statistical Release G.19- Consumer CreditNovember 7, 2018.
} 
borrowing, investment, savings, and output levels. The lending channel of monetary policy postulates that when the Fed decreases (increases) interest rates such as the fed funds rate, the cost of borrowing for banks decreases (increases), and therefore banks tend to lend more (less) to consumers and affecting levels of consumption. Several studies, including Bernanke and Gertler (1995), Perez (1998), Bernanke et al. (2005), Stein (2012), Hsing (2014), and Stein (2021) have developed and explored the literature on the lending channel.

While current monetary policy targets the fed funds rate and is supplemented by unconventional practices, its ultimate purpose is to provide funds to the economy in order to stabilize and/or improve economic conditions by decreasing the cost of borrowing and stimulating consumption. Monetary actions of the Fed directly and instantly affect the fed funds rate, influencing the cost of borrowing for banks and financial institutions. The cost of borrowing, however, may not significantly affect households. It is a question of how responsive interest rates on consumer loans are to monetary policy changes. Given the ratio of revolving consumer debt to total consumer debt of about $26.05 \%$ as of December 2019, and credit card debt comprising approximately $76.76 \%$ of the revolving consumer debt ${ }^{4}$, the change in the cost of borrowing through credit cards implies significant implications for monetary policy, especially when monetary policy efforts aim to stimulate consumption in the short run.

One important implication of borrowing through credit cards in the context of monetary policy is that credit card loans may not respond to monetary policy changes. Credit card rates and consumer behavior regarding credit cards show dispersions among consumers in the United States (Stango and Zinman 2016). Credit card rates tend to be irresponsive to other interest rates fluctuations in financial markets (Mester 1994; Calem and Mester 1995; Valadkhani et al. 2014; and Agarwal et al. 2018). Credit cards may have a counter, or crowding-out effect, during adverse credit conditions. During a market downturn, central bank authorities often conduct expansionary monetary policy and quantitative easing to reduce interest rates, provide liquidity in credit markets, and increase aggregate consumption. In the US, the Fed has actively used the fed funds rate as one of its monetary policy tools and set target rates since the 1970s. During market downturns, the Fed decreases the fed funds rate to provide liquidity and stimulate the economy. At the same time, credit card companies typically increase credit card rates and tighten credit card loans to mitigate risk as consumer creditworthiness deteriorates due to higher unemployment rates or wage cuts. Therefore, consumption through credit cards may crowd out the effect of an expansionary monetary policy that targets short-term interest rates in financial markets such as the fed funds rate.

Understanding the effectiveness of the monetary policy on aggregate consumption and aggregate demand requires knowing the short-term and long-term consumption elasticity of household consumption to changes in consumer loan rates and the elasticity of consumer loan rates to changes in the fed funds rate. Theory suggests that when an expansionary monetary policy decreases the fed funds rate, the rate on other funds, particularly on funds available for consumption in the form of credit card loans should also decrease, resulting in an increase in demand for consumer credits, and ultimately an increase in aggregate consumption and the GDP.

In recent years, several studies observe inefficacies in the traditional transmission mechanism and varying effects on different banks. Tenreyro and Thwaites (2016) find that monetary policy shocks have smaller effects on output and inflation in times of contraction than expansion. Albertazzi et al. (2021) find the transmission is weaker for banks with stronger capital and

\footnotetext{
${ }^{4}$ Authors' calculation based on the Fed's Consumer Credit (G.19 data series) and Consumer Loans data compiled by the Board of Governors of the Federal Reserve System as of December 2019. The ratio of $26.05 \%$ is based on the total revolving credit owned and securitized of $\$ 1.092$ trillion and total consumer credit owned and securitized of $\$ 4.192$ trillion. The ratio of $76.76 \%$ is based on the outstanding credit card and other revolving plans from all commercial banks, excluding credit card loans from noncommercial banks such as credit unions or savings and loan institutions. The data was last accessed through https://fred.stlouisfed.org/series/TOTALSL, https://fred.stlouisfed.org/series/REVOLSL, and https://fred.stlouisfed.org/series/CCLACBW027SBOG on 09/15/2021.
} 
funding positions than smaller banks with minimal capital holdings. They argue that the ultra-low interest rates during economic downturns add to the inefficacy of monetary policy.

The near-zero interest rates during the financial crisis of 2007-2008 compelled many central banks to resort to unconventional monetary policies such as quantitative easing, forward guidance, direct asset purchases, and auctioning off term loans. The unconventional policies are based on the view that frictions in credit markets create additional channels to influence aggregate demand using processes involving bank lending as well as effects on the balance sheets of firms and/or households. This credit channel of monetary policy alters the amount of credit households and firms have access to, thus leading to fluctuations in overall spending and investment.

2.2. Synthesis of empirical research in the field. Perhaps the most prominent departure from conventional monetary policies was the creation of emergency lending facilities of the Fed during the financial crisis of 2007-2008. Zia (2014) studies the emergency lending facilities of the Fed during the financial crisis of 2007-2008 and finds that the Fed created seven unprecedented emergency lending facilities and provided a cumulative $\$ 7.77$ trillion to the US financial system. Both the scope and the amount of unconventional loans were unprecedented. Salachas et al. (2017) document that unconventional monetary policy efforts, such as asset purchases, were more effective than conventional initiatives and helped to restore the bank-lending channel following the Great Recession of 2007-2008. Kuttner (2018) and Ippolito et al. (2018) find that unconventional policy efforts were successful in lowering long-term interest rates and that these observed rate reductions influenced spending decisions of households and firms, as well as lending decisions of financial institutions. Laine (2021) supplements Kutner (2018) and Ippolito et al. (2018) studies and finds that unconventional monetary policy efforts increased credit offerings to non-financial institutions, but had insignificant effects on loans for household consumption. Afonso and Sousa-Leite (2019) and Albertazzi et al. (2021) observe that unconventional monetary policy efforts were transmitted more by banks with relatively strong capital and funding positions, suggesting that banks' lending responses were largely affected by balance sheet constraints.

Other studies investigate the effects of monetary policy on household consumption. Auclert (2019) demonstrates the role of various redistribution channels and how those channels affect consumption through monetary policy efforts. He observes large and heterogeneous marginal propensities to consume and attributes them to household balance sheets. This result supports several earlier studies observing heterogeneity in consumption and income responses among households (Ekici and Dunn 2010; Meier and Springer 2010; Shen and Giles 2006; Souleles 2004; Telyukova 2013). Other studies such as Brady (2011), Coibion et al. (2017), Guerrieri and Lorenzoni (2017), and Holm et al. (2020) find monetary policy shocks to have significant and persistent effects on income and consumption inequality, particularly for low-income households, which dilute the desired effect of monetary policies.

The literature documents inefficacies in monetary policy in recent decades but falls short of identifying the causes. The diminished efficacy in the lending channel of monetary policy may be due to developments and innovations in consumer loan products such as credit card loans in the past couple of decades. Credit cards serve as instant loans or a method of borrowing with pre-determined interest rates. One important implication of borrowing through credit cards in the context of monetary policy is that the revolving nature of credit card loans may not respond to monetary policy due to the stickiness of credit card interest rates. Gross and Souleles (2002) find that cardholders are more responsive to an increase in their credit limit, but observed that decreases in credit card rates were ineffective in changing consumer behavior. These results suggest the revolving nature of credit card loans may not respond to monetary policy efforts due to the stickiness of credit card interest rates. Calem and Mester (1995) study credit card interest rates and consumer behavior in the United States. Their findings suggest a relative stickiness or downward rigidity of credit card interest rates. Several studies 
support the stickiness of credit card interest rates, observing that credit cardholders are not very responsive to changes in credit card interest rates (Stavins 2000; Yu et al. 2003; Telyukova 2013; Valadkhani et al. 2014).

The stickiness of credit card interest rates complicates the implication of monetary policy through the credit card channel. The investigation of how credit card utilization, as a means of consumer spending, reacts to the fed funds rate fluctuations will shed light on the efficacy of monetary policy and its influence on household consumptions expenditures. The purpose of this paper is to discuss various complications that credit cards may introduce to the efficacy of monetary policy.

\section{Data Description}

Data for the federal funds rate, consumer price index (CPI), saving rate, and disposable income comes from the Economic Research Division of the Federal Reserve Bank of St. Louis. Data about consumer revolving credit balances, non-revolving credit balances, as well as total balances, are obtained from the statistical releases of the Board of Governors of the Federal Reserve System and its triennial Survey of Consumer Finances (SCF) reports, the G.19 data series $^{5}$. While data on the fed funds rate, consumer price index (CPI), and disposable income are available for many decades, data on consumer credit cards and total debt balances are available since $1968^{6}$. However, it is not until the 1980s that revolving credits in the form of credit cards became common. Therefore, we use the data from the first quarter of 1980 to the last quarter of 2018. Our dataset consists of 152 quarterly observations.

Quarterly data on credit card interest rates are available since the last quarter of 1994 . Therefore, wherever we use credit card interest rates in our analysis, we limit our models to quarterly data since the last quarter of 1994.

\begin{tabular}{|c|c|c|c|c|c|}
\hline \multicolumn{6}{|c|}{ Table 1: Descriptive Statistics of Variables } \\
\hline Variables & Obs & Mean & Std.Dev. & Min & Max \\
\hline Revcc & 152 & 614.521 & 287.591 & 135.851 & 1018.389 \\
\hline ffrate & 152 & 4.810 & 4.087 & 0.070 & 17.780 \\
\hline ccrate & 93 & 13.570 & 1.474 & 11.820 & 16.140 \\
\hline$c c-f f s p r e a d$ & 93 & 10.993 & 1.415 & 7.81 & 14.13 \\
\hline srate & 152 & 6.503 & 2.328 & 2.200 & 12.400 \\
\hline nonrevcc & 152 & 1297.111 & 490.572 & 697.530 & 2415.174 \\
\hline$d i$ & 152 & 8483.012 & 2561.786 & 4523.133 & 12827.330 \\
\hline$G D P$ & 152 & 11694.450 & 3332.793 & 6382.892 & 17371.850 \\
\hline unemp & 152 & 5.355 & 0.469 & 4.614 & 6.210 \\
\hline$c c i$ & 152 & 86.569 & 12.677 & 52.700 & 112.000 \\
\hline \multicolumn{6}{|l|}{ Notes: } \\
\hline \multicolumn{6}{|c|}{$\begin{array}{l}\text { The variables are outstanding quarterly balance of revolving credit in billions (Revcc), average federal funds rate } \\
\text { in percentage (ffrate), average credit card interest rate in percentage (ccrate), the spread between credit card } \\
\text { rate and federal funds rate (cc-ff spread), saving rate as percentage of disposable income (srate), non-revolving } \\
\text { consumer credit balance in billions (nonrevcc), disposable income in billions (di), GDP in billions, unemployment } \\
\text { rate (unemp) and consumer confidence index (cci). }\end{array}$} \\
\hline \multicolumn{6}{|c|}{ Observations are from the $1980 \mathrm{q} 1$ to $2018 \mathrm{q} 4$, except for the credit card rate, which is over 1994q4-2018q4. } \\
\hline \multicolumn{6}{|c|}{$\begin{array}{l}\text { Revolving consumer credit, non-revolving consumer credit, disposable income, and GDP are in } 2009 \text { dollars. The } \\
\text { consumer confidence index is set as } 1966 \mathrm{q} 1=100 \text {. All data are from the Federal Reserve Bank of St. Louis. }\end{array}$} \\
\hline
\end{tabular}

\section{Methodology}

Since the variables in our analysis are time-series in nature, we test them first for stationarity utilizing Dickey-Fuller tests and modify the variables to make them stationary when needed

\footnotetext{
${ }^{5}$ Survey of Consumer Finances is a report released every three years. The next data release is scheduled for 2022. As a result, we limited our analysis to the years prior to 2019.

${ }^{6}$ This is perhaps credit cards were not popular before 1968, given that Charge Card (which evolved to the current Master Card) was introduced in 1966.
} 
such as taking their lag-differences, percentage change, or natural logs where appropriate. We also realize that the fed funds rate as one of the monetary policy tools is determined by the Federal Reserve System based on market conditions such as the unemployment rate, growth of GDP, or consumer confidence index $(\mathrm{CCI})^{7}$. Therefore, the fed funds rate may be an endogenous variable causing endogeneity problems in ordinary least square (OLS) regressions. To address this problem, we utilize instrumental variables and estimate our models using a two-stage least square (2SLS) model where the fed funds rate is the instrumented (endogenous) variable. We set the following model to test bank revolving credit response to the fed funds rate:

$$
\text { Revcc }_{i}=\beta_{0}+\beta_{1} \widehat{\text { frate }}_{i}+\beta_{2} \text { srated }_{i}+\beta_{3} \text { lognonrevcc }_{i}+\beta_{4} \log _{i}+\varepsilon_{i},
$$

for $i=1980 \mathrm{q} 1-2018 \mathrm{q} 4$.

The fed funds rate is our instrumented variable and is estimated as:

$$
\text { frated }_{i}=\beta_{0}+\beta_{1} g d p_{i-1}+\beta_{2} \text { unemp }_{i-1}+\beta_{3} c c i_{i-1}+u_{i},
$$

where:

Revcc $_{i}$ : Inflation-adjusted change in revolving consumer credit balance in billions, in 2009 dollars

ffrate ${ }_{i}$ : The change in fed funds rate over the previous quarter

$\int \widehat{\text { frate }} d_{i}$ : The fitted fed funds rate

srate $_{i}$ : The change in savings rate over the previous quarter

lognonrevcc $_{i-1}$ : Logarithm of outstanding non-revolving consumer credit balance in the previous quarter in billions, in 2009 dollars ${ }^{8}$

$\log d i_{i}$ : The natural log of disposable income in billions, in 2009 dollars

$\beta_{1} g d p_{i-1}$ : GDP growth rate in the previous quarter

$\beta_{2}$ unemp $_{i-1}$ : The unemployment rate in the previous quarter

$\beta_{3} c c i_{i-1}$ : Consumer confidence index in the previous quarter

$\varepsilon_{i}$ and $u_{i}$ : The error terms.

The variable of interest in Model (1) is the fed funds rate coefficient $\left(\beta_{1}\right)$. A negative and significant coefficient would mean that when the fed funds rate is set lower by the Fed to decrease the cost of borrowing and stimulate the economy. A negative coefficient implies the effectiveness of monetary policy through the bank revolving credit (credit cards) channel. A positive and significant coefficient would imply the crowding-out effect of the credit card channel on monetary policy targeting the fed funds rate. When the fed funds rate is set lower, consumers spend less through the credit card channel and thereby crowding out the effect of monetary policy. An insignificant coefficient would imply diminished efficacy of monetary policy through the credit card channel.

In Model (2) below, we incorporate the interest rate on credit cards to Model (1) to control for the rates on credit card loans and test credit card loans' response to credit card rates.

$$
\operatorname{Revcc}_{i}=\beta_{0}+\beta_{1} \widehat{\text { frate }}_{i}+\beta_{2} \text { ccrated }_{i}+\beta_{3} \text { srated }_{i}+\beta_{4} \text { lognonrevcc }_{i}+\beta_{5} \log _{i}+\varepsilon_{i},
$$

for $i=1994 \mathrm{q} 1-2018 \mathrm{q} 4$.

Like in Model 1, the fed funds rate ( f frated) is the instrumented variable and estimated based on lags of the GDP growth rate, unemployment rate, and consumer confidence index. The

\footnotetext{
${ }^{7}$ While monetary policy is set through deliberations in the Federal Open Market Committee of the Fed and is mostly discretionary, a non-discretionary approach proposed by John Taylor (1993), which is known as the Taylor Rule, can bring insight to the endogeneity discussion.

${ }^{8}$ The non-revolving credit balance in the previous quarter is a control variable accounting for the indebtedness of consumers that may limit consumers' willingness or ability to utilize credit card loans. A better control variable for their ability to utilize credit card loans is perhaps the FICO credit score for individuals. However, the focus of this research is not on individual determinants of credit card use, but on aggregate levels of credit card loans in response to fed funds rate as the monetary policy target.
} 
variable ccrate $_{i}$ is the change in credit card interest rate in quarter $i$ from the previous quarter. All other variables are as defined before.

The variables of interest in Model (2) are the fed funds rate and credit card interest rate coefficients, $\beta_{1}$ and $\beta_{2}$, respectively. As in Model (1), $\beta_{1}$ would test credit card loan response to the fed funds rate changes but unlike in Model (1), it takes into account the credit card interest rate changes. $\beta_{2}$ tests for the responsiveness of credit card loans to fluctuations in the credit card interest rate. A statistically significant $\beta_{2}$ would indicate that consumption through credit card loans responds to credit card interest rate fluctuations. An insignificant $\beta_{2}$ would indicate irresponsive consumption through the credit card channel to credit card interest rate changes.

A further question arises whether consumers' credit card use is correlated with the general level of credit card interest rates relative to the fed funds rate. For instance, the spread between credit card interest rates and the fed funds rate could be relatively high (low) when the fed funds rate is low (high). The spread between credit card rates and the fed funds rate, therefore, can capture the relative fluctuations in credit card interest rates. To test whether credit card loans respond to the spread between the credit card interest rate and the fed funds rate, we set the following model:

$$
\operatorname{Revcc}_{i}=\beta_{0}+\beta_{1} \widehat{\text { frate }}_{i}+\beta_{2} \text { ccff } f_{i}+\beta_{3} \text { srated }_{i}+\beta_{4} \text { lognonrevcc }_{i}+\beta_{5} \log _{\text {og }}+\varepsilon_{i},
$$

for $i=1994 \mathrm{q} 1-2018 \mathrm{q} 4$.

The variable $\operatorname{crff} f_{i}$ is the quarterly spread between the consumer credit card rate and the fed funds rate. All the other variables are as previously defined.

4.1. Robustness Checks. For robustness purposes, we utilize three approaches and retest our models. First, we test whether the results change during financial crises. Second, we employ robust standard errors to account for possible heteroscedasticity, and third, we run the models for periods of pre-financial crisis of 2007-2008 (pre-Great Recession) and post-Great Recession to test for possible shifts in consumers' approach to revolving credits and credit card loans.

The credit trap hypothesis developed by Benmelech and Bergman (2012) states that under certain circumstances, such as during a financial crisis, monetary policy effectiveness may become limited. Consumers may find themselves unable to take advantage of economic opportunities or increase their credit card balances when interest rates decrease during an economic downturn or financial crisis. Consumer behavior during a crisis may differ significantly from non-crisis periods. To test whether consumers' consumption through revolving credit changes significantly during a financial crisis from non-crisis periods in response to interest rate changes, we retest Model (1) and (2) for crisis periods versus non-crisis periods. We use the National Bureau of Economic Research (NBER) classification of financial crises to identify crisis periods since $1980^{9}$. We report the results for the crisis versus non-crisis periods along with each other for easy comparison. We also use a dummy-variable approach to test whether any structural change in consumer behavior regarding credit card loans is significant during a financial crisis.

Since interest rates, in general, have fluctuated considerably since the 1980 s, we may have a shift in the variances of our variables. Therefore, we may have a heteroscedasticity problem in our analysis. To account for such a problem, we use robust standard errors in our estimations.

The Great Recession of 2007-2008 and its aftermath regulations such as the Dodd-Frank Wall Street Reform and Consumer Protection Act (Dodd-Frank Act) brought about awareness in consumers regarding credit card loans. One of the major changes in the credit card industry has been the explicit disclosure of interest rates, fees, and dollar amounts of interest charges in credit card statements. The act, along with disclosure requirements, may have affected consumer tendencies to use credit card loans. To check for possible shifts in consumer behavior regarding credit cards loans, we retest Model (1) and (2) for two sub-periods, the pre-Great

\footnotetext{
${ }^{9}$ The National Bureau of Economic Research (NBER) classification of financial crises in the U.S. since 1980 includes the following periods: 1980q1, 1981q1-1982q1, 1989q3-1990q4, 2000q4-2001q2, and 2007q3-2009q1.
} 
Recession, and the post-Great Recession. We define the pre-Great Recession period from the first quarter of 1980 to the last quarter of 2006 and the post-Great Recession period from the last quarter of 2009 to the last quarter of $2018^{10}$.

\section{Part 1. Results and Discussion}

Estimated results do not show a significant correlation between bank revolving credit and fluctuations in the fed funds rate. Additionally, the results do not vary significantly from the pre-Great Recession period to the post-Great Recession period. Table 2 presents the results from Model (1).

The table presents two-state least squares (2SLS) regression results for Model (1): $\operatorname{Revcc}_{i}=$ $\beta_{0}+\beta_{1} \widehat{\text { frate }}_{i}+\beta_{2}$ srated $_{i}+\beta_{3}$ lognonrevcc $_{i}+\beta_{4}$ logdi $_{i}+\varepsilon_{i}$, for i=1980q1-2018q4, where the federal funds rate (ffrated) is the instrumented variable and estimated based on lags of GDP growth rate, unemployment rate, and consumer confidence index: ffrated $_{i}=\beta_{0}+\beta_{1} g d p_{i-1}+$ $\beta_{2}$ unemp $_{i-1}+\beta_{3} c c i_{i-1}+u_{i}$. Revcc $_{i}$ is the quarterly change in revolving consumer credit balance in billions; frated $_{i}$ is the quarterly change in the federal funds rate; srated $_{i}$ is the quarterly change in saving rate; lognonrevcc ${ }_{i}$ is the logarithm of non-revolving consumer credit balance in billions; $\log d i_{i}$ is the $\log$ of disposable income levels in billions; $\varepsilon_{i}$ and $u_{i}$ are the error terms. The crises periods refer to the periods when the U.S. economy was in recession according to the National Bureau of Economic Research (NBER). These periods include 1980q1, 1981q11982q1, 1989q3-1990q4, 2000q4-2001q2 and 2007q3-2009q1. All data are from the Federal Reserve Bank of St. Louis. All variables in dollars are in real terms adjusted to 2009 dollars.

\begin{tabular}{|c|c|c|c|c|c|c|}
\hline \multicolumn{7}{|c|}{ Table 2: Model (1) Regression Results } \\
\hline & \multicolumn{2}{|c|}{ All periods } & \multicolumn{2}{c|}{ Non-crises periods } & \multicolumn{2}{c|}{ Crises periods } \\
\hline Variables & Coefficients & P-Values & Coefficients & P-Values & Coefficients & P-Values \\
\hline f frated & 4.621 & 0.087 & 5.401 & 0.070 & 0.951 & 0.916 \\
\hline srated & 0.314 & 0.782 & -0.596 & 0.644 & 2.154 & 0.709 \\
\hline lognonrevcc & -11.434 & 0.180 & -8.091 & 0.360 & -61.894 & 0.502 \\
\hline logdi & 4.665 & 0.639 & -1.509 & 0.888 & 63.060 & 0.488 \\
\hline cons & 44.545 & 0.229 & 76.073 & 0.072 & -122.648 & 0.473 \\
\hline $\mathrm{N}$ & 151 & & 129 & & 21 & \\
\hline F-statistic & $7.01^{* * *}$ & 0.0000 & $7.02^{* * *}$ & 0.0000 & 1.73 & 0.187 \\
\hline R-squared & 0.2569 & & 0.2889 & & 0.4820 & \\
\hline Adjusted $\mathrm{R}^{2}$ & 0.2203 & & 0.2477 & & 0.2031 & \\
\hline \multicolumn{7}{|c|}{ Legend: $*$ for $5 \%, * *$ for $1 \%$ and $* * *$ for $0.1 \%$ significance levels. } \\
\hline
\end{tabular}

The coefficient for the fed funds rate $\left(\beta_{1}\right)$ for the period 1980q1-2018q4 is 4.621 but not statistically significant at $5 \%$ level. It implies that quarterly change in revolving credit balance or consumption through credit card loans is irresponsive to changes in the fed funds rate, the primary target of the Federal Reserve System when conducting monetary policy. The coefficient remains statistically insignificant during both crises and non-crises periods. The insignificant coefficient implies that bank revolving credit generally does not respond to the fed fund rates either during financial crises or during normal economic conditions.

While the results of Model (1) provide insight into the relationship of revolving credit and the fed funds rate since 1980, it does not control for credit card interest rate fluctuations. Model (2) controls for the fluctuations in credit card rates and Table 3 presents the results.

The table presents two-state least squares (2SLS) regression results for Model (2): $\operatorname{Revcc}_{i}=$ $\beta_{0}+\beta_{1}$ frated $_{i}+\beta_{2}$ crrated $_{i}+\beta_{3}$ srated $_{i}+\beta_{4}$ lognonrevcc $_{i}+\beta_{5}$ logdi $i_{i}+\varepsilon_{i}$, for $\mathrm{i}=1994 \mathrm{q} 1-$ $2018 \mathrm{q} 4$, where the federal funds rate (ffrated) is the instrumented variable and estimated based

\footnotetext{
${ }^{10}$ Based on the NBER classification, the Great Recession officially started in the third quarter of 2007 and ended in the first quarter of 2009. To avoid any contamination effect from the Great Recession, we set the pre-Great Recession and post-Great Recession periods two quarters away from the Great Recession period.
} 


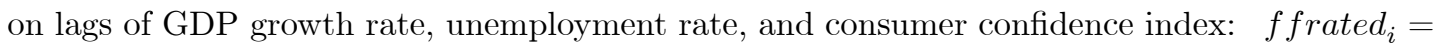
$\beta_{0}+\beta_{1} g d p_{i-1}+\beta_{2}$ unemp $_{i-1}+\beta_{3} c c i_{i-1}+u_{i}$. Revcc $_{i}$ is the quarterly change in revolving consumer credit balance in billions; f frated $_{i}$ is the quarterly change in the federal funds rate; srated $_{i}$ is the quarterly change in saving rate; lognonrevcc $i$ is the logarithm of non-revolving consumer credit balance in billions; $\log d i_{i}$ is the log of disposable income levels in billions; $\varepsilon_{i}$ and $u_{i}$ are the error terms. The crises periods refer to the periods since 1994 when the U.S. economy was in recession according to the National Bureau of Economic Research (NBER). These periods include two recessions: 2000q4-2001q2 and 2007q3-2009q1. All data are from the Federal Reserve Bank of St. Louis. All variables in dollars are in real terms adjusted to 2009 dollars.

\begin{tabular}{|c|c|c|c|c|c|c|}
\hline \multicolumn{7}{|c|}{ Table 3: Model (2) Regression Results } \\
\hline & \multicolumn{2}{|c|}{ All periods } & Non-crises periods & \multicolumn{2}{c|}{ Crises periods } \\
\hline Variables & Coefficients & P-Values & Coefficients & P-Values & Coefficients & P-Values \\
\hline f frated & -4.065 & 0.525 & 28.443 & 0.242 & 3.615 & 0.811 \\
\hline ccrated & 6.674 & 0.168 & -0.570 & 0.956 & -6.929 & 0.472 \\
\hline srated & 2.213 & 0.121 & 1.087 & 0.526 & 7.838 & 0.313 \\
\hline lognonrevcc & $126.157^{* * *}$ & 0.000 & $157.467^{* * *}$ & 0.000 & 622.254 & 0.135 \\
\hline logdi & $-233.452^{* * *}$ & 0.000 & $-288.442^{* * *}$ & 0.000 & -886.309 & 0.111 \\
\hline cons & $123.232^{* * *}$ & 0.000 & $1506.055^{* * *}$ & 0.000 & 3641.781 & 0.087 \\
\hline $\mathrm{N}$ & 92 & & 82 & & 10 & \\
\hline F-statistic & $76.12^{* * *}$ & 0.0000 & $7.41^{* * *}$ & 0.0000 & 1.01 & 0.6507 \\
\hline R-squared & 0.371 & & 0.4482 & & 0.8900 & \\
\hline Adjusted $\mathrm{R}^{2}$ & 0.3106 & \multicolumn{7}{|c|}{0.3877} & & 0.0104 & \\
\hline \multicolumn{7}{|c|}{ Legend: * for $5 \%, * *$ for $1 \%$ and $* * *$ for $0.1 \%$ significance levels. } \\
\hline
\end{tabular}

Table 3 shows the coefficient results of -4.065 and 6.674 for the fed funds rate and credit card rate for all periods. The coefficients are not significant at all. The coefficients for the nonrevolving credit balance and disposable income are statistically significant at the $0.1 \%$ level for the non-crises periods. The results imply that credit card loans respond neither to the fed funds rate nor to credit card rates. Rather, credit card loans seem to be determined by the outstanding non-revolving credit balance and disposable income during non-crises periods only. During financial crises, however, none of the variables significantly explains the fluctuations in credit card loans. The unresponsiveness of credit card loans during financial crises supports the liquidity trap hypothesis.

We also test whether there is a structural change in revolving credit during financial crises. We utilize a dummy variable approach and retest Model (1), Model (2), and Model (3) by setting a dummy variable for financial crises periods. The results indicate that the coefficient for the crises dummy variable for Model (2) is statistically significant at the $0.1 \%$ level with a p-value of 0.000, while for Model (1) and Model (3) it is not significant at all with p-values of 0.363 and 0.160 , respectively. These results from the dummy variable approach are consistent with the results reported in Table 2 and Table $3^{11}$.

The coefficients during crises periods in Table 3 show an interesting result of this study. None of the coefficients during the financial crises period is significant. It implies that consumption through revolving credit is determined by other factors than the fed funds rate, credit card rates, traditional savings rate, outstanding non-revolving credit balance, and disposable income. One explanation might be the deterioration of consumer confidence in the economy, which is implicitly controlled for in our 2SLS model via the fed funds instrumented variable. Another might be the tightening of credit terms by financial institutions. The tightening of credit or other circumstances prohibiting consumers from utilizing more revolving credits when the Fed sets

\footnotetext{
${ }^{11}$ Other results with a dummy variable approach are not reported as they do not differ significantly from the results presented in Table 2 and Table 3 and may create confusion. Dummy variable results may be directly requested from the authors.
} 
interest rates lower supports the credit trap hypothesis. The exact reasons why consumption through credit cards does not respond to the variables during financial crises is a subject beyond the primary scope of this paper that requires consumer behavior analysis.

The financial crisis of 2007-2008, the Great Recession, brought about major changes in financial markets. One of the changes was the Dodd-Frank Wall Street Reform and Consumer Protection Act. The act mandated financial institutions, particularly credit card issuing companies, to disclose clearer information about the term and conditions of credit card loans. For instance, it mandated the disclosure of the length of time required to pay off revolving loans, the total interest rate charges during the period, and the amount of savings in interest charges if consumers made a hypothetical payment more than the minimum required on their statements.

On the other hand, the crisis itself exposed borrowers to the distress of having revolving credit balances during economic downturns. Lending institutions may also decrease borrowing limits during economic downturns, creating downward pressure on borrowing activities. Alonso (2018) shows that a credit crunch produces a more severe drop in consumption when there is an exogenous decrease in borrowing limits relative to an exogenous increase in interest rates. Such changes may have shifted consumers' approach to using revolving credit in the aftermath of the Great Recession, causing shifts in the efficacy of monetary policy targeting the fed funds rate. To test for this, we retest Model (1) and (2) for the pre-Great Recession and post-Great Recession periods. Table 4 presents the results.

Table 4. Two-Stage-Least Square (2SLS) Regression Results for Model (1) and Model (2) for the Pre-Great Recession and Post-Great Recession Periods

Table 4 presents results for Model (1) and Model (2) for pre-Great Recession period (i=1980q1$2006 \mathrm{q} 4)$ and post-Great Recession period $(\mathrm{i}=2009 \mathrm{q} 4-2018 \mathrm{q} 4) . \mathrm{Revcc}_{i}$ is the quarterly change in revolving consumer credit balance in billions; frate $_{i}$ is the quarterly change in the federal funds rate; ccrate $_{i}$ is the quarterly change in credit card rates; $s r_{i}$ is the quarterly change in saving rate; lognonrevcc $i$ is the logarithm of non-revolving consumer credit balance in billions; $\log d i_{i}$ is the $\log$ of disposable income levels in billions and $\varepsilon_{i}$ is the error term. All data are from the Federal Reserve Bank of St. Louis. All variables in dollars are in real terms adjusted to 2009 dollars.

Model (1): Revcc $_{i}=\beta_{0}+\beta_{1}$ f $\widehat{\text { frate }}_{i}+\beta_{2}$ srated $_{i}+\beta_{3}$ lognonrevcc $_{i}+\beta_{4}$ logdi $_{i}+\varepsilon_{i}$, where is the instrumented variable and estimated in the $1^{\text {st }}$ stage of the regression based on the following model: frated $_{i}=\beta_{0}+\beta_{1} g d p_{i-1}+\beta_{2}$ unemp $_{i-1}+\beta_{3} c c i_{i-1}+u_{i}$

\begin{tabular}{|c|c|c|c|c|}
\hline \multicolumn{5}{|c|}{ Panel A: Regression results for Model (1) } \\
\hline & Pre-Great Recession & \multicolumn{2}{c|}{ Post-Great Recession } \\
\hline Variables & Coefficients & P-Values & Coefficients & P-Values \\
\hline f frated & 1.085 & 0.583 & -16.780 & 0.638 \\
\hline srated & 0.243 & 0.829 & 0.654 & 0.579 \\
\hline lognonrevcc & $-17.675^{*}$ & 0.032 & $105.563^{* *}$ & 0.013 \\
\hline logdi & $20.619^{* *}$ & 0.012 & -67.194 & 0.585 \\
\hline cons & -52.418 & 0.095 & -173.897 & 0.840 \\
\hline $\mathrm{N}$ & 48 & & 33 & \\
\hline F-statistic & 1.30 & 0.2583 & $44.27^{* * *}$ & 0.0000 \\
\hline R-squared & 0.0850 & & 0.9253 & \\
\hline Adjusted $\mathrm{R}^{2}$ & 0.0196 & & 0.9044 & \\
\hline \multicolumn{5}{|c|}{ Legend: ${ }^{*}$ for $5 \%, * *$ for $1 \%$ and $* * *$ for $0.1 \%$ significance levels. } \\
\hline
\end{tabular}

Panel A of Table 4 shows that revolving credit remains irresponsive to changes in the fed funds rate during both pre- and post-Great Recession periods. Whereas, revolving credit responds to credit card rate changes in the pre-Great Recession period. The coefficient for the credit card interest rate (ccrated) is 19.853 and significant at $1 \%$ level with a p-value of 0.007 in the pre-Great Recession period while -8.598 and insignificant in the post-Great Recession period. 
This change in the sign and significance of the credit card rate coefficient implies that in the preGreat Recession period, consumers borrowed more whenever credit card interest rates increased, whereas, in the post-Great Recession period, they borrowed less when credit card interest rates increased. This result provides further evidence that consumers may have become more aware of the interest rate charged on their credit cards balances.

Model (2): Revcc $_{i}=\beta_{0}+\beta_{1}{\text { f } \widehat{\text { frate }_{i}}}_{i}+\beta_{2}$ crated $_{i}+\beta_{3}$ srated $_{i}+\beta_{4}$ lognonrevcc $_{i}+$ $\beta_{5} \log d i_{i}+\varepsilon_{i}$ where is the instrumented variable and estimated in the $1^{\text {st }}$ stage of the regression based on the following model: frated $_{i}=\beta_{0}+\beta_{1}$ gdp $_{i-1}+\beta_{2}$ unemp $_{i-1}+\beta_{3}$ cci $_{i-1}+u_{i}$

\begin{tabular}{|c|c|c|c|c|}
\hline \multicolumn{5}{|c|}{ Panel B: Regression results for Model (2) } \\
\hline & Pre-Great Recession & Post-Great Recession \\
\hline Variables & Coefficients & P-Values & Coefficients & P-Values \\
\hline f frated & -11.323 & 0.119 & 12.138 & 0.776 \\
\hline srated & $19.853^{* *}$ & 0.007 & -8.598 & 0.141 \\
\hline ccrated & 1.090 & 0.621 & 0.582 & 0.641 \\
\hline lognonrevcc & -22.561 & 0.707 & $130.643^{* *}$ & 0.008 \\
\hline logdi & 9.581 & 0.918 & -141.746 & 0.314 \\
\hline cons & 84.371 & 0.843 & 333.706 & 0.732 \\
\hline $\mathrm{N}$ & 48 & & 33 & \\
\hline F-statistic & $3.29^{* *}$ & 0.0058 & $37.83^{* * *}$ & 0.0000 \\
\hline R-squared & 0.4026 & & 0.9265 & \\
\hline Adjusted $\mathrm{R}^{2}$ & 0.2801 & & 0.9020 & \\
\hline \multicolumn{5}{|c|}{ Legend: $*$ for $5 \%, * *$ for $1 \%$ and $* * *$ for $0.1 \%$ significance levels. } \\
\hline
\end{tabular}

To further investigate whether credit card loans respond to the general level of credit card rates relative to the fed funds rate during different sub-periods, we test Model (3) and report the results in Table 5.

Table 5. Two-Stage-Least Square (2SLS) Regression Results for Model (3) for the Non-Recession, Recession, Pre-Great Recession, and Post-Great Recession Periods

Table 5 presents results for Model (3) for non-recession periods since 1994q1, recession periods since 1994q1 (2000q4-2001q2 and 2007q3-2009q1), pre-Great Recession period (i=1980q12006q4) and post-Great Recession period (i=2009q4-2018q4).

Model (3): Revcc $_{i}=\beta_{0}+\beta_{1}$ ffrated $_{i}+\beta_{2}$ ccff $f_{i}+\beta_{3}$ srated $_{i}+\beta_{4}$ lognonrevcc $_{i}+$ $\beta_{5} \log d i_{i}+\mathcal{E}_{i}$ where is the instrumented variable and estimated in the $1^{\text {st }}$ stage of the regression based on the following model: frated $_{i}=\beta_{0}+\beta_{1}$ gdp $_{i-1}+\beta_{2}$ unemp $_{i-1}+\beta_{3} c c i_{i-1}+u_{i}$.

\begin{tabular}{|c|c|c|c|c|c|c|}
\hline Table 5 (I) & \multicolumn{2}{|c|}{ All periods } & \multicolumn{2}{c|}{ Non-Recession periods } & \multicolumn{2}{c|}{ Recession periods } \\
\hline Variables & Coefficients & P-Values & Coefficients & P-Values & Coefficients & P-Values \\
\hline ffrated & -2.744 & 0.633 & 17.070 & 0.287 & 5.754 & 0.463 \\
\hline cc-ffspread & $-5.155^{* * *}$ & 0.000 & -3.269 & 0.075 & $-4.715^{*}$ & 0.046 \\
\hline srated & 2.065 & 0.076 & 1.111 & 0.426 & $11.12^{*}$ & 0.045 \\
\hline lognonrevcc & $138.936^{* * *}$ & 0.000 & $148.180^{* * *}$ & 0.000 & $687.185^{*}$ & 0.024 \\
\hline logdi & $-235.689^{* * *}$ & 0.000 & $-258.494^{* * *}$ & 0.000 & $-988.680^{*}$ & 0.018 \\
\hline cons & $1214.770^{* * *}$ & 0.000 & $1334.865^{* * *}$ & 0.000 & $4161.529^{* *}$ & 0.012 \\
\hline $\mathrm{N}$ & 93 & & 83 & & 83 & \\
\hline F-statistic & $14.88^{* * *}$ & 0.0000 & $14.10^{* * *}$ & 0.0000 & 9.97 & 0.2405 \\
\hline R-squared & 0.5863 & & 0.6039 & & 0.6039 & \\
\hline Adjusted $\mathrm{R}^{2}$ & 0.5469 & & 0.5611 & & 0.5611 & \\
\hline
\end{tabular}

Revcc $_{i}$ is the quarterly change in revolving consumer credit balance in billions; frated $_{i}$ is the quarterly change in federal funds rate; $\operatorname{ccrff} f_{i}$ is the quarterly spread between the consumer credit card rate and the federal funds rate; srated $_{i}$ is the quarterly change in saving rate; 
lognonrevcc $_{i-1}$ is the logarithm of non-revolving consumer credit balance in billions in the previous quarter; $\log d i_{i}$ is the log of disposable income level in billions; and $\varepsilon_{i}$ and $u_{i}$ are the error term. All data are from the Federal Reserve Bank of St. Louis. All variables in dollars are in real terms adjusted to 2009 dollars.

\begin{tabular}{|c|c|c|c|c|}
\hline Table 5 (II) & \multicolumn{2}{|c|}{ Pre-Great Recession Period } & \multicolumn{2}{c|}{ Post-Great Recession Period } \\
\hline Variables & Coefficients & P-Values & Coefficients & P-Values \\
\hline ffrated & -12.506 & 0.072 & 16.261 & 0.587 \\
\hline cc-ffspread & $-6.848^{* *}$ & 0.010 & $-9.6534^{* * *}$ & 0.000 \\
\hline srated & 2.0711 & 0.375 & -0.091 & 0.930 \\
\hline lognonrevcc & 52.495 & 0.469 & 38.223 & 0.307 \\
\hline logdi & -114.362 & 0.311 & -10.275 & 0.920 \\
\hline cons & 745.623 & 0.161 & -78.7000 & 0.912 \\
\hline $\mathrm{N}$ & 48 & & 33 & \\
\hline F-statistic & $2.36^{*}$ & 0.0350 & $37.70^{* * *}$ & 0.0000 \\
\hline R-squared & 0.3206 & & 0.9263 & \\
\hline Adjusted $\mathrm{R}^{2}$ & 0.1847 & & 0.9017 & \\
\hline \multicolumn{4}{|c|}{ Legend: $^{*}$ for $5 \%, * *$ for $1 \%$ and $*^{* * *}$ for $0.1 \%$ significance levels. } \\
\hline
\end{tabular}

The coefficient for the credit card rate and the fed funds rate spread (cc-ff spread) is consistently negative and significant at or less than the $5 \%$ significance level. In the pre-Great Recession period, the coefficient is -6.848 and significant at $1 \%$ whereas, in the post-Great Recession it becomes -9.6534 and significant at $0.1 \%$. This increase in the significance of the spread further supports the notion that consumers may have become more informed about and aware of interest rate charges on their credit cards in the post-Great Recession period.

The overall findings of this paper indicate that the bank revolving credit in the form of credit card loans does not generally respond to a monetary policy targeting the fed funds rate but to the spread between the two interest rates. This interesting result implies that the spread between revolving consumer credit rates and the fed funds rate is more important in determining consumption in the context of monetary policy.

\section{Summary and Conclusion}

The fed funds rate as one of the monetary policy tools and its implications on aggregate consumption and the state of the economy have been extensively investigated. However, its implication through the bank revolving credit channel (credit cards channel) has not been adequately studied. Over the past two decades with the popularity of the Internet, credit cards have become a major tool utilizing transactions and providing consumers with instant access to consumer loans. This instant access to consumer loans makes credit cards an important element in the monetary policy implications. In this paper, we investigated whether bank revolving credit responds to the fed funds rate or credit card rate fluctuations, as well as the spread of the two rates. We utilized the instrument variables technique and two-stage least squares (2SLS) methodology to account for endogeneity and possible omitted variable problems. We also performed tests in different periods such as during financial crises, non-crises, pre-Great Recession, and post-Great Recession periods.

Our results show that when the Fed targets the fed funds rate as one of its monetary policy tools, bank revolving credit in the form of credit card loans does not respond to changes in the fed funds rate, thereby, diminishing the efficacy of the fed funds rate as a monetary policy tool. We find that, in general, credit card loan balances do not respond to the fed funds rate or credit card rates. Rather, it responds to the spread of credit card rates and the fed funds rate, especially in the post-Great Recession period. These findings imply that the spread between credit card rates and the fed funds rate is an important element of the credit card channel of monetary policy rather than the fed funds rate alone. 
This study has four main implications. One implication is that the fed funds rate as a monetary policy tool does not work effectively through the bank revolving credit channel (credit cards channel). The second implication is that credit card loans do not respond to credit card rates. This supports the credit trap hypothesis developed by Benmelech and Bergman (2012). The third implication is that bank revolving credit balances respond well to the spread between the credit card rates and the fed funds rate, which implies that consumers take into consideration the interest rate charged on their credit cards relative to other interest rates, such as the fed funds rate. The last, but not least, implication is that this paper serves as an empirical study of the growing credit card popularity and its implication as a channel of monetary policy. The most important contribution of this paper is that it complements the research literature on bank revolving credit in the context of monetary policy.

This paper has several shortcomings. For instance, the number of observations is limited to 151 quarters in Model (1) and 92 quarters in Model (2) and Model (3). This is due to the nature of a few variables such as GDP and unemployment rates being released quarterly. Also, no data is available on credit card interest rates before 1994. Another shortcoming of this study is the lack of explanatory variables capturing consumer behavior pertaining to credit cards use. A variable capturing marketing expenditures on credit card commercials and solicitations may also improve this study. General financial education of consumers, or their approach to credit cards, may also be a factor in determining how much credit card or other revolving loans they use. Such consumer behavioral parameters are important factors determining the use of credit cards and other revolving loans. However, analyzing consumer behavior pertaining to credit card use is well beyond the scope and purpose of this paper in which we analyze aggregate bank revolving credit in the form of credit card balances as a channel of monetary policy targeting the fed funds rate. Further research on the causes of inefficacies in the transmission mechanism of monetary policy and the determinants of bank revolving credit would enrich the literature on this channel of monetary policy. We hope to see more research in this interesting field.

\section{REFERENCES}

[1] Afonso, António, and Joana Sousa-Leite. 2020. "The transmission of unconventional monetary policy to bank credit supply: evidence from the TLTRO." The Manchester School 88: 151-171.

[2] Agarwal, Sumit, Souphala Chomsisengphet, Neale Mahoney, and Johannes Stroebel. 2018. "Do banks pass through credit expansions to consumers who want to borrow?" The Quarterly Journal of Economics 133, no. 1: 129-190.

[3] Albertazzi, Ugo, Andrea Nobili, and Federico M. Signoretti. 2021. "The bank lending channel of conventional and unconventional monetary policy." Journal of Money, Credit and Banking 53, no. 2-3: 261-299. https://doi.org/10.1111/jmcb.12766.

[4] Alonso, Cristian. 2018. "Hard vs. soft financial constraints: Implications for the effects of a credit crunch." Journal of Macroeconomics 58: 198-223.

[5] Auclert, Adrien. 2019. "Monetary policy and the redistribution channel." American Economic Review 109, no. 6: 2333-67. https://doi.org/10.1257/aer.20160137.

[6] Benmelech, Efraim, and Nittai K. Bergman. 2012. "Credit traps." American Economic Review 102, no. 6: 3004-32.

[7] Bernanke, Ben s. and Alan S. Blinder. 1992. "The Federal funds rate and the channels of monetary transmission. American Economic Review 82, no. 4: 901-921.

[8] Bernanke, Ben S., and Mark Gertler. 1995. "Inside the black box: the credit channel of monetary policy transmission." Journal of Economic Perspectives 9, no. 4: 27-48.

[9] Bernanke, Ben S., Jean Boivin, and Piotr Eliasz. 2005. "Measuring the effects of monetary policy: a factoraugmented vector autoregressive (FAVAR) approach." The Quarterly Journal of Economics 120, no. 1: 387-422.

[10] Brady, Ryan R. 2011. "Consumer credit, liquidity, and the transmission mechanism of monetary policy." Economic Inquiry 49, no. 1: 246-263. doi:10.1111/j.1465-7295.2010.00297.

[11] Coibion, Olivier, Yuriy Gorodnichenko, Lorenz Kueng, and John Silvia. 2017. "Innocent bystanders? Monetary policy and inequality." Journal of Monetary Economics 88: 70-89.

[12] Calem, Paul S., and Loretta J. Mester. 1995. "Consumer behavior and the stickiness of credit-card interest rates." The American Economic Review 85, no. 5: 1327-1336. 
[13] Drechsler, Itamar, Alexi Savov, and Philipp Schnabl. 2018. "A model of monetary policy and risk premia." The Journal of Finance 73, no. 1: 317-373.

[14] Ekici, Tufan, and Lucia Dunn. 2010. "Credit card debt and consumption: evidence from household-level data." Applied Economics 42, no. 4: 455-462.

[15] Goodfriend, Marvin. 2011. "Central banking in the credit turmoil: an assessment of the Federal Reserve practice." Journal of Monetary Economics 58, no. 1: 1-12.

[16] Gross, David B., and Nicholas S. Souleles. 2002. "Do liquidity constraints and interest rates matter for consumer behavior? Evidence from credit card data." The Quarterly Journal of Economics 117, no. 1: 149-185.

[17] Guerrieri, Veronica, and Guido Lorenzoni. 2017. "Credit crises, precautionary savings, and the liquidity trap." The Quarterly Journal of Economics 132, no. 3: 1427-1467. https://doi.org/10.1093/qje/qjx005.

[18] Holm, Martin Blomhoff, Pascal Paul, and Andreas Tischbirek. 2020. "The Transmission of Monetary Policy under the Microscope," Federal Reserve Bank of San Francisco Working Paper, (March). https://doi.org/10.24148/wp2020-03.

[19] Hsing, Yu. 2014. "Test of the bank lending channel: the case of US consumer loans." Applied Economics Letters 21, no. 7: 466-46.

[20] Ippolito, Filippo, Ali K. Ozdagli, and Ander Perez-Orive. 2018. "The transmission of monetary policy through bank lending: The floating rate channel." Journal of Monetary Economics 95: 49-71. https://doi.org/10.1016/j.jmoneco.2018.02.0010304-3932.

[21] Kuttner, Kenneth N. 2018. "Outside the box: Unconventional monetary policy in the great recession and beyond." Journal of Economic Perspectives 32, no. 4: 121-46. https://doi.org/10.1257/jep.32.4.121

[22] Laine, Olli-Matti. 2021."The Effect of Targeted Monetary Policy on Bank Lending." Journal of Banking and Financial Economics 1, no. 15: 25-43. https://10.7172/23536845jbfe- 2021.1.3.

[23] Meier, Stephan, and Charles Sprenger. 2010. "Present-biased preferences and credit card borrowing." American Economic Journal: Applied Economics 2, no. 1: 193-210. https://doi.10.1257/app.2.1.193.

[24] Mester, Loretta J. 1994. "Why are credit card rates sticky?" Economic Theory 4, no. 4: 505-530.

[25] Perez, Stephen J. 1998. "Causal ordering and 'The bank lending channel'." Journal of Applied Econometrics 13, no. 6: 613-626.

[26] Salachas, Evangelos N., Nikiforos T. Laopodis, and Georgios P. Kouretas. 2017. "The bank-lending channel and monetary policy during pre-and post-2007 crisis." Journal of International Financial Markets, Institutions and Money 47: 176-187. http://dx.doi.org/10.1016/j.intfin.2016.10.0031042-4431.

[27] Shen, Kaili, and David E. Giles. 2006. "Rational exuberance at the mall: addiction to carrying a credit card balance." Applied Economics 38, no. 5: 587-592.

[28] Souleles, Nicholas S. 2004. "Expectations, heterogeneous forecast errors, and consumption: Micro evidence from the Michigan consumer sentiment surveys." Journal of Money, Credit and Banking 36: 39-72.

[29] Stango, Victor, and Jonathan Zinman. 2016. "Borrowing high versus borrowing higher: price dispersion and shopping behavior in the US credit card market." The Review of Financial Studies 29, no. 4: 979-1006.

[30] Stavins, Joanna. 2000. "Credit card borrowing, delinquency, and personal bankruptcy." New England Economic Review, (July): 15-30.

[31] Stein, Jeremy C. 2012. "Monetary policy as financial stability regulation." The Quarterly Journal of Economics 127, no. 1: 57-95.

[32] Stein, Jeremy C. 2021. "Can Policy Tame the Credit Cycle?" IMF Economic Review 69, no. 1: 5-22.

[33] Taylor, John B. 1993. "Discretion versus policy rules in practice." Carnegie-Rochester Conference Series on Public Policy, no. 39: 195-214. North-Holland.

[34] Telyukova, Irina A. 2013. "Household need for liquidity and the credit card debt puzzle." Review of Economic Studies 80, no. 3: 1148-1177.

[35] Tenreyro, Silvana, and Gregory Thwaites. 2016. "Pushing on a string: US monetary policy is less powerful in recessions." American Economic Journal: Macroeconomics 8, no. 4: 43-74. https://dx.doi.org/10.1257/mac.20150016.

[36] Valadkhani, Abbas, Sajid Anwar, and Amir Arjomandi. 2014. "Downward stickiness of interest rates in the Australian credit card market." Journal of the Asia Pacific Economy 19, no. 1: 52-65.

[37] Yu, Hsing, Jo-Anne Gibson, Lin Tin-Chun, and Dawn Wallace. 2003. "Determinants of credit card rates and policy implications." International Journal of Management 20, no. 3: 395-400.

[38] Zia, Mujtaba. 2014. "Bank Capital, Efficient Market Hypothesis, and Bank Borrowing during the Financial Crisis of 2007 and 2008" (Doctoral Dissertation, University of North Texas). UNT Digital Library: https://digital.library.unt.edu/ark:/67531/metadc699938/.

[39] Zia, Mujtaba, Imre Karafiath, and Niranjan Tripathy. 2018. "Bank Capital, the Announcement of the Federal Reserve's Term Auction Facility, and Bank Borrowing during the Financial Crisis of 2007-2008." Journal of Financial Research 41, no. 4: 485-506. 